https://helda.helsinki.fi

\title{
The Pluralist Character of the European Economic Constitution
}

\section{Miettinen, Timo Pekka Antero}

2018-10

Miettinen , T P A 2018 , ' The Pluralist Character of the European Economic Constitution ' , European law review, vol. 43 , no. 4 , pp. 613-615.

http://hdl.handle.net/10138/257511

draft

Downloaded from Helda, University of Helsinki institutional repository.

This is an electronic reprint of the original article.

This reprint may differ from the original in pagination and typographic detail.

Please cite the original version. 
Lastly, the question of substantive citizenship is present both in Bierbach's discussion on the situation of black US citizens (p.188) and in his suggestion that cross-border equality can in many situations be understood as an attempt "to increase substantive equality with host member state national" and "to reduce the substantive barriers to freedom of movement" (pp.243-244). It nonetheless seems that this insight is not fully applied to the position of economically inactive EU citizens. The concluding chapter mentions the Dano judgment and the accepted derogations from equal treatment in the context of social assistance (p.434). However, the author does not further analyse how the de facto exclusion of economically vulnerable EU citizens from many aspects of substantive EU citizenship rights might challenge the finding that "[e]quality ... is no longer merely an accessory to economic activity, but is itself the goal of Union citizenship, in the vision of the Court" (p.434).

The book converses with a broad selection of academic literature, although the chronological approach means that the more recent literature is at times under-represented. The author refers to "the perspective of critical legal theory and the history of the text itself" (p.58), as well as to "a textual analysis" (p.112) and "a critical legal perspective" (p.178), in discussing the development of US citizenship. Otherwise, it remains more implicit how these methods and perspectives shape the book and its findings. Situating the research questions within the broader field of comparative constitutionalism at the beginning of the book might have helped the author to stay more focused on this aspect of his argument throughout the book.

However, this book provides an impeccable overview of the constitutional histories of US and EU citizenship, and it also makes a fresh and welcome contribution to the comparative analysis of US and EU citizenship from a distinctively vertical theoretical perspective. I therefore warmly recommend Bierbach's book to readers who are interested in the comparative study of these two "duplex citizenships", as well as to anyone who would like to revise their knowledge of the key cases and constitutional developments around US and/or EU citizenships from a historical perspective.

Päivi Johanna Neuvonen University of Helsinki

\section{The Pluralist Character of the European Economic Constitution, by Clemens Kaupa, (Oxford: Hart Publishing, 2016), 400pp., hardback, £60, ISBN: 9781509901081.}

The prolonged crisis of European economies has spurred new interest in the founding ideas and elements of the European economic model. This concerns particularly the Economic and Monetary Union (EMU) of the EU and its three-stage development from free movement of capital to fiscal harmonisation and the creation of the "euro zone" with a single currency. Especially in the legal scholarship, much of this debate has revolved around the concept of "economic constitution". The concept has primarily referred to the legal structure and instruments of the EMU and is often divided into micro- and macro-economic components. Following the German tradition of ordoliberalism, the concept has also encompassed questions of social and political "order": in this regard, the understanding of a particular economic system depends not only on the accepted "rules of the game" but on a number of social and political choices.

Clemens Kaupa's The Pluralist Character of the European Economic Constitution (2016) is a fine contribution to this debate. With a breadth of analysis that goes beyond typical legal scholarship, Kaupa illuminates the various genealogies of the European economic constitution and its recent transformations through the euro crisis. Kaupa's work is a fine example of the idea that a genuine understanding of the economic constitution can only be achieved by an interdisciplinary approach that takes into account not only the legal dimension but also questions of political institutions, social models and wider ideological premises. Kaupa's work is an important reminder of that fundamental ambiguity and openness that characterises the Treaties, especially when it comes to economic matters. 
The work itself is divided into five main chapters: the analysis of the Treaty of Rome (Ch.1), the birth of the Maastricht Treaty (Ch.2), market and case law as examples of the economic constitution (Ch.3), the role of economics (Ch.4), and the euro crisis and its impact on the macroeconomic constitution (Ch.5). Methodologically, the work moves between historical and doctrinal analysis, combining case law examples with wider political and economic analyses. In line with legal positivism, the key methodological hypothesis is that the "law/politics distinction is established and constantly reconstructed within legal discourse, and is not based on some alleged intrinsic difference" (p.9). While the euro crisis itself originated as one of sovereign debt, it has revealed major structural problems within the EMU, challenging traditional ideas of national sovereignty, democracy and the division between executive and legislative powers. The economic constitution is a fickle instrument that both strengthens hegemonic power and can be turned against it.

The intellectual and ideological origins of the contemporary economic constitution have recently been under debate. In this debate, the key issue has been whether the institutional and constitutional choices of the EMU have followed either the broad intellectual tradition of German ordoliberalism, a more narrow understanding of neoclassical economic (i.e. the neo-classical synthesis), or a particular national tradition(s) based on the political influence of particular State(s). Kaupa's strategy here is somewhat different from the case of typical narratives that often tell the story from a particular viewpoint. In his view, the European economic constitution should be understood as a fundamentally pluralistic instrument that reflects a number of competing socio-economic paradigms and allows for a variety of socio-political strategies. Instead of telling the story of a particular hegemonic tradition, we should emphasise the fundamental ideological ambiguity that is characteristic of the Treaties. In those cases where a clear ideological bias can be found (e.g. the Greek loan programmes and their implementation), we should attribute this primarily to political choices and interpretations.

The argument on pluralism may seem uninteresting at first glance. Why not pick one narrative and argue for that? Should it not be the aim of academic scholarship to make things clearer, rather than more ambiguous? Kaupa's argument, however, is more interesting. The point is not simply to say that the motives of the economic constitution are various, but rather to construct a philosophical argument according to which the typical conceptual distinctions applied to integration are in many regards insufficient. In relation to the Treaty of Rome, for instance, distinctions between economic and non-economic objectives, or negative and positive integration, are in many ways misleading (p.17). In the context of the 1950s, the idea or concept of "economic integration" was a deeply contested concept that served several purposes, from the removal of tariffs to the coordination of macroeconomic policies, but also to more general "equalization of the conditions of production and trade", as Commissioner Marjolin put it in 1957. It is thus problematic to subscribe to the standard argument in European Studies according to which the post-Second World War integration was primarily "economic" in character. While the EEC naturally was a very different political animal than the League of Nations, for instance, the meaning and scope of "economic" integration was in reality far more ambiguous than today. What is thus needed is a more nuanced understanding of the historical context of the Treaties.

Still, there are some open questions that allow room for further analysis. At times, Kaupa's emphasis on the pluralistic character of the economic constitution is close to a kind of lack of decision that is highly critical of the very idea of explaining as such. For instance, while it is true that the Treaty of Rome stressed the importance of both free economic exchange as well as a regulatory framework, thus combining elements from both Keynesian and ordoliberal traditions, French and German visions, could it not be argued that the fundaments of the economic constitution were in fact closer to the ordoliberal vision of a competitive economic order? Take for instance the Stability and Growth Pact (SGP) that focuses on fiscal discipline or the rejection of joint liability in the Treaties - these were fundamentally ordoliberal ideas in line with Germany's interests. 
Thus it is somewhat surprising to find Kaupa describing the "price stability rule" of the European Central Bank as a pluralist tool (p.289). After all, the emphasis on price stability as the primary objective of the central bank is a fundamentally ordoliberal principle that has been a part of the German Bundesbank since the post-Second World War era. The fact that the ECB was modelled after the Bundesbank has been widely documented and acknowledged in the literature. The fact that the nominal inflation target $(2$ per cent) was not agreed in the Treaties or that the ECB has pursued a variety of strategies in order to tackle deflation in the crisis years is not yet an indication of competing socio-economic paradigms. And, while Kaupa is right in pointing out that the supervisory mechanisms of the Stability and Growth Pact leave considerable room for discretion (p.300), we should keep in mind that most of the northern euro area countries have consistently ruled out all fiscal instruments that would genuinely be about the creation of demand (e.g. the euro area budget).

To put it differently, it still remains an open question why, despite the evident plurality characteristic of the European economic constitution, the austerity-driven approach of Germany and other northern countries has dominated the crisis management. If the Treaties would allow for greater flexibility (p.336), why has this not been pursued to promote different socio-economic goals? Is this still due to the fact that the dominant responses to the euro crisis followed the standard neo-classical theories such as the expansionary fiscal contraction hypothesis, or was the primary approach of the euro elite that of ordoliberal moralism that put the blame on weak countries such as Greece?

Perhaps one of the inferences of the book is that the "neoliberal thought and practice" (p.1) characteristic of the post-war era is in fact an ambiguous concept that allows for several political interpretations and institutional strategies. As Kaupa demonstrates, especially the ordoliberal interpretation of neoliberalism was in many ways less dogmatic than the kind of moralistic liberalism or libertarianism pursued by the Austrian School. It was exactly this kind of adaptability to the new institutional strategies and socio-political goals that made ordoliberalism so influential in post-war Germany and the early EEC. Despite the fact that the ECB, in its pursuit to tackle deflation in the crisis years, may have not followed the strict policies advocated by hardline ordoliberals such as Hans-Werner Sinn, it may be concluded that the unconventional measures have still contributed to the larger goal of keeping the euro area afloat.

Timo Miettinen

University of Helsinki

Environmental Principles and the Evolution of Environmental Law, by Eloise Scotford, (Oxford: Hart Publishing, 2017), 320pp., hardback, £60, ISBN: 9781849462976.

A significant number of international environmental treaties and domestic legislations encapsulate an array of principles, ranging from the integration of environmental concerns into all policy areas, to sustainable development. It comes thus as no surprise that environmental principles such as polluter-pays, prevention and precaution have a high profile in environmental law. However, in spite of their success, these principles are still elusive.

This book aims, on the one hand, to demonstrate how courts apply environmental principles with the aim of developing legal reasoning, and, on the other, to show how these principles are "highly charged concepts for scholars in thinking about the nature of environmental law as a discipline". As a matter of course, the two issues are entangled, given that case law reckons upon doctrinal opinions. In particular, environmental scholars have played, for at least 40 years, a pivotal role in the codification of that legal discipline and the proclamation of a flurry of principles and new concepts. 